Jurnal Kesehatan

Volume 12, Nomor 2, Tahun 2021

ISSN 2086-7751 (Print), ISSN 2548-5695 (Online)

http://ejurnal.poltekkes-tjk.ac.id/index.php/JK

\title{
Peningkatan Kadar Hemoglobin Ibu Hamil Anemia dengan Kombinasi Pemberian Tablet Fe dan Madu
}

\section{Increased Hemoglobin Levels of Pregnant Women Anemia with Combination of Tablets Fe and Honey}

\author{
Ahmady $^{1}$, Zulhaini Sartika A. Pulungan ${ }^{2}$, Edi Purnomo ${ }^{3}$ \\ ${ }^{1}$ Jurusan Kebidanan, Politeknik Kesehatan Kemenkes Mamuju, Indonesia \\ ${ }^{2,3}$ Jurusan Keperawatan, Politeknik Kesehatan Kemenkes Mamuju, Indonesia
}

\section{ARTICLE INFO}

\section{Article history}

Received date

14 Jun 2021

Revised date

23 Jun 2021

Accepted date

03 Aug 2021

Keywords:

Anemia;

Fe tablets;

Honey;

Pregnant women;

Kata kunci:

Anemia;

Tablet Fe;

Madu;

Ibu hamil.

\section{ABSTRACT/ ABSTRAK}

\begin{abstract}
The problem for pregnant women is iron anemia. The natural material that contains iron is honey. The study aims to determine the difference in hemoglobin levels in pregnant anemic who are supplemented Fe tablets and honey. Quasi-experimental research with nonrandomized pretest and posttest with control group design. Samples amounted to 30 people with purposive sampling technique. Analysis using paired t-test and independent sample t-test. The hemoglobin levels of anemic pregnant given Fe tablets only increased by $0,31 \mathrm{gr} / \mathrm{dl}(3,21 \%)$, while those given $\mathrm{Fe}$ tablets and honey increased $1,06 \mathrm{gr} / \mathrm{dl}$ $(12,20 \%)$. Combination $\mathrm{Fe}$ tablets and honey can be an alternative for increasing hemoglobin in anemic pregnant.
\end{abstract}

Permasalahan ibu hamil adalah anemia zat besi. Bahan alam yang mengandung zat besi adalah madu. Penelitian bertujuan mengetahui perbedaan kadar hemoglobin ibu hamil anemia yang mendapat suplementasi tablet $\mathrm{Fe}$ dan madu. Penelitian eksperimen semu dengan rancangan nonrandomized pretest and posttest with control group design. Sampel berjumlah 30 orang dengan teknik purposive sampling. Analisis menggunakan paired $t$ test dan independent sample t-test. Kadar hemoglobin ibu hamil anemia yang diberi tablet Fe hanya meningkat $0,31 \mathrm{gr} / \mathrm{dl}(3,21 \%)$, sedangkan yang diberi tablet Fe dan madu meningkat $1,06 \mathrm{gr} / \mathrm{dl}(12,20 \%)$. Kombinasi tablet $\mathrm{Fe}$ dan madu dapat menjadi alternatif untuk peningkatan hemoglobin ibu hamil anemia.

Corresponding Author:

Zulhaini Sartika A. Pulungan,

Jurusan Keperawatan Politeknik Kesehatan Kemenkes Mamuju, Indonesia

Email: zulhainisartika@gmail.com

\section{PENDAHULUAN}

Anemia merupakan masalah kesehatan masyarakat secara global baik negara berkembang maupun negara maju. Berdasarkan data World Health Organization (2015) terdapat 32,4 juta atau sekitar $38 \%$ ibu hamil mengalami anemia di seluruh dunia. Bila dibandingkan dengan data anemia di Indonesia berdasarkan hasil Riskesdas tahun 2013, anemia pada populasi ibu hamil menurut kriteria yang ditentukan WHO dan pedoman Kementerian Kesehatan, adalah sebesar $37,1 \%$ dan proporsinya hampir sama antara ibu hamil di perkotaan $(36,4 \%)$ dan di perdesaan $(37,8 \%)$ (Kementerian Kesehatan RI, 2013).

Anemia dapat terjadi pada semua tahap siklus kehidupan, namun anak-anak dan wanita usia subur merupakan kelompok yang paling berisiko. Hal ini akan berdampak pada kehidupan 
jutaan perempuan dan anak-anak di seluruh dunia. Anemia berkontribusi pada peningkatan jumlah kemiskinan, penurunan kapasitas kerja, peningkatan kematian ibu dan perkembangan motorik dan kognitif yang lambat pada anak (WHO, 2015).

Anemia pada wanita hamil, dapat meningkatkan frekuensi komplikasi pada kehamilan dan persalinan. Risiko kematian maternal, angka prematuritas, berat badan bayi lahir rendah, dan angka kematian perinatal meningkat. Di samping itu, perdarahan antepartum dan postpartum lebih sering dijumpai pada wanita yang anemis dan lebih sering berakibat fatal, sebab wanita yang anemia tidak dapat mentolerir kehilangan darah. Dampak anemia pada kehamilan bervariasi dari keluhan yang sangat ringan hingga terjadinya gangguan kelangsungan kehamilan (abortus, partus imatur/prematur), gangguan proses persalinan (inertia, atonia, partus lama, perdarahan atonis), gangguan pada masa nifas (subinvolusi rahim, daya tahan terhadap infeksi dan stres kurang, produksi ASI rendah), dan gangguan pada janin (abortus, dismaturitas, mikrosomi, BBLR, kematian perinatal, dan lain-lain) (Citrakesumasari, 2012).

Anemia yang dialami ibu hamil pada umumnya merupakan anemia relatif yang diakibatkan oleh perubahan fisiologis tubuh selama kehamilan (Kementerian Kesehatan RI, 2013). Anemia fisiologis terjadi selama kehamilan yang sehat karena peningkatan volume plasma yang lebih besar dibandingkan dengan peningkatan massa sel darah merah. Konsentrasi hemoglobin dan hematokrit pada ibu hamil yang tidak mengonsumsi suplemen zat besi selama kehamilan, dapat terus menurun sekitar $2 \mathrm{gr} / \mathrm{dl}$ lebih rendah dari konsentrasi hemoglobin sebelum kehamilan. Kondisi ini terjadi pada usia kehamilan 28-36 minggu, karena transfer zat besi melalui plasenta paling intens selama periode ini, sehingga mengurangi ketersediaan besi untuk eritropoiesis ibu. Untuk itu perlu percepatan untuk memenuhi kebutuhan zat besi fisiologis pada ibu hamil, baik penyerapan zat besi dari makanan maupun mobilisasi zat besi dari simpanan tubuh. Penyerapan zat besi dari makanan yang mengandung zat besi dalam jumlah tinggi hanya sekitar 3-4 mg/hari, dengan demikian peningkatan penyerapan zat besi dari makanan tidak cukup untuk memenuhi kebutuhan kehamilan. Selain itu, banyak wanita pada saat memasuki masa kehamilan dengan simpanan zat besi yang tidak mencukupi, yang menyebabkan wanita mengalami defisiensi zat besi selama kehamilan (Fisher, 2020).
Penanggulangan masalah anemia di Indonesia dilakukan dengan mencanangkan pemerataan pendistribusian tablet $\mathrm{Fe}$ ke pelayanan-pelayanan kesehatan untuk dapat dibagikan ke seluruh ibu hamil secara gratis. Pendistribusian tersebut termasuk salah satu target capaian dalam Asuhan Antenatal Care (ANC). Salah satu frekuensi kunjungan dalam ANC adalah cakupan $\mathrm{Fe} 1$ dan $\mathrm{Fe} 3$. Pemberian tablet zat besi pada ibu hamil dapat dibedakan menjadi $\mathrm{Fe} 1$ yang mendapat 30 tablet dan $\mathrm{Fe} 3$ yang mendapat 90 tablet selama masa kehamilan. Pemberian tablet besi minimal 90 tablet selama kehamilan juga merupakan salah satu penerapan operasional dari standar minimal $7 \mathrm{~T}$ untuk pelayanan antenatal. Program pemerintah yang telah dijalankan terlihat pada angka cakupan pemberian tablet $\mathrm{Fe} 3$ pada ibu hamil di Indonesia tahun 2011 mencapai 83,3\% yang hampir mencapai target nasional yaitu sebesar $86 \%$. Ditinjau dari kepatuhan ibu hamil dalam mengkonsumsi tablet besi menunjukkan cakupan di Indonesia hanya 19,3\% (Kementerian Kesehatan RI 2013; Kementerian Kesehatan RI, 2016).

Berdasarkan Profil Kesehatan Kabupaten Mamuju, pada tahun 2015 persentase ibu hamil yang mendapatkan tablet Fe1 (30 tablet) sebesar $88,49 \%$, Fe3 (90 tablet) sebesar 76,26\%. Data anemia di Puskesmas yang ada di Kota Mamuju (Puskesmas Binanga, Bambu dan Tampa Padang) menunjukkan anemia ibu hamil $(\mathrm{Hb}<11 \mathrm{mg} / \mathrm{dl})$ tahun 2015 berjumlah 107 orang dari 464 orang, tahun 2016 berjumlah 102 orang dari 308 orang. Dilihat dari persentase ini angka kejadian anemia di Mamuju semakin meningkat. Hal ini juga ditunjukkan dari data kunjungan ANC, kunjungan K1 di Kabupaten Mamuju tahun 2015 sebesar 92,2\%, mengalami penurunan dari tahun 2014 sebesar 99,91\%. Cakupan kunjungan K4 tahun 2015 sebesar 83,6\%, mengalami penurunan dari tahun 2014 sebesar 89,78\% (Dinas Kesehatan Kab. Mamuju, 2015).

Program pemerintah yang telah dijalankan merupakan suatu langkah yang ditempuh dalam rangka menurunkan kejadian anemia, namun anemia defisiensi besi pada ibu hamil masih merupakan masalah kesehatan yang belum teratasi. Masalah ini juga yang mengakibatkan angka kematian ibu di Kabupaten Mamuju tahun 2015 sebesar 218 per 100.000 kelahiran hidup mengalami peningkatan jika dibandingkan dengan tahun 2014 yaitu sebesar 152 per 100.000 kelahiran hidup. Angka kematian ibu di Kabupaten Mamuju tahun 2015 masih jauh dari target MDGs sebesar 102 per 100.000 kelahiran hidup (Dinas Kesehatan Kab. Mamuju, 2015). 
Pemberian tablet Fe yang dilakukan secara umum di puskesmas tidak menunjukkan peningkatan yang bermakna terhadap kadar haemoglobin ibu hamil anemia. Hal ini disebabkan ketidakpatuhan terhadap suplementasi yang diberikan sejak awal kehamilan. Ketidakpatuhan terjadi karena efek samping yang ditimbulkan seperti mual, muntah, pusing serta efek pada saluran pencernaan bawah (diare dan konstipasi). Kurangnya pengetahuan ibu juga mempengaruhi kepatuhan mengkonsumsi tablet $\mathrm{Fe}$, seperti warna feses yang berubah membuat ibu cemas dan takut untuk melanjutkan mengkonsumsi tablet $\mathrm{Fe}$ tersebut.

Melihat kondisi masyarakat tersebut peneliti tertarik menambahkan pemberian tablet Fe dengan madu. Madu adalah makanan alami yang dihasilkan oleh lebah madu. Peradaban kuno menganggap madu sebagai Dewa dan produk yang sangat bergengsi. Banyak literatur yang menyatakan pentingnya madu di hampir semua negara dan semua agama. Secara fisik, madu merupakan bahan kental dan jelly yang tidak memiliki warna tertentu. Secara kimiawi, madu adalah campuran kompleks dari banyak senyawa organik dan anorganik seperti gula, protein, asam organik, pigmen, mineral, dan banyak elemen lainnya. Penggunaan madu sebagai agen terapi sudah lama digunakan setua peradaban manusia. Sebelum munculnya obat-obatan saat ini, madu secara konvensional digunakan untuk mengobati banyak penyakit. Saat ini, penelitian modern telah membuktikan pentingnya madu untuk pengobatan (Khan, et al., 2018).

National Honey Board menyatakan bahwa madu mengandung asam sekitar $0,57 \%$, protein $0,266 \%$, nitrogen $0,043 \%$, asam amino $0,1 \%$, mineral $0,17 \%$, dan beberapa komponen lain, seperti fenol, koloid, dan vitamin, yang semuanya membentuk sekitar 2,1\% dari seluruh komposisi madu. Beberapa kandungan mineral dalam madu diantaranya: belerang (S), kalsium $(\mathrm{Ca})$, tembaga $(\mathrm{Cu})$, mangan $(\mathrm{Mn})$, besi $(\mathrm{Fe})$, fosfor (P), klor (Cl), kalium (K), magnesium $(\mathrm{Mg})$, iodium $(\mathrm{I})$, seng $(\mathrm{Zn})$, silikon $(\mathrm{Si})$, natrium (Na), molibdenum (Mo) dan aluminium (Al) sedangkan potasium merupakan mineral utama pada madu. Madu pun mengandung vitamin diantaranya vitamin $\mathrm{E}$, vitamin $\mathrm{C}$ serta vitamin B1, B2, B6. Madu juga memiliki keasaman yang rendah dengan $\mathrm{pH}$ 3,9 (Syuhar, et al., 2014).

Kandungan $\mathrm{Fe}$, protein, vitamin, dan mineral dalam madu dapat meningkatkan produksi zat besi dalam darah. Sumsum tulang memerlukan prekursor seperti zat besi, vitamin C, vitamin B12, kobalt dan hormon untuk pembentukan sel darah merah dan hemoglobin.
Semua unsur ini terkandung dalam madu, sehingga mengkonsumsi madu dapat mencegah anemia defisiensi besi pada ibu hamil (Wulandari, 2015).

\section{METODE}

Penelitian ini merupakan penelitian eksperimen semu atau quasy experiment dengan rancangan non randomized pre test and post test with control group design. Penelitian ini bertujuan untuk mengetahui perbedaan peningkatan kadar hemoglobin ibu hamil anemia yang mendapat suplementasi tablet Fe dan tablet Fe dengan madu di Kota Mamuju.

Populasi dalam penelitian ini adalah semua ibu hamil yang berkunjung dan dilakukan pemeriksaan kadar hemoglobin di wilayah kerja Puskesmas Binanga, Bambu dan Tampa Padang Kabupaten Mamuju sebanyak 308 orang. Teknik penarikan sampel menggunakan metode purposive sampling, dengan kriteria ibu hamil anemia $(\mathrm{Hb}<11 \mathrm{gr} / \mathrm{dl})$, mendapatkan suplementasi tablet Fe dari puskesmas dan bersedia menjadi responden. Jumlah sampel keseluruhan adalah 30 orang, dikelompokkan menjadi 2 kelompok: kelompok kontrol hanya mengkonsumsi tablet $\mathrm{Fe}$, kelompok perlakuan mengkonsumsi tablet $\mathrm{Fe}$ dan madu. Masing-masing kelompok berjumlah 15 orang dan diberi intervensi selama 14 hari.

Variabel bebas dalam penelitian ini adalah tablet $\mathrm{Fe}$ dan madu. Tablet $\mathrm{Fe}$ yang diberikan adalah tablet tambah darah buatan Kimia Farma jenis fero sulfat diminum 1 kali sehari. Madu yang diberikan adalah madu hutan Gholiban ${ }^{\circledR}$ yang diberikan dengan dosis $1,5 \mathrm{gr} / \mathrm{Kg} \mathrm{BB} /$ hari. Jika berat badan ibu hamil $60 \mathrm{Kg}$ maka madu yang diberikan sebanyak 90 gram (setara dengan 9 sendok makan) yang dibagi dalam 3 kali pemberian (pagi, sore, malam). Sebelum diberikan kepada ibu hamil madu terlebih dahulu ditimbang menggunakan timbangan digital dan dibagi dalam 3 sachet untuk memudahkan ibu meminum madu tersebut. Variabel terikatnya adalah nilai hemoglobin dalam darah ibu hamil yang diukur sebelum dan sesudah intervensi pada kelompok kontrol dan kelompok perlakuan. Alat ukur yang digunakan NESCO Multi Check 2.

Analisis data dilakukan dengan analisis univariat dengan menampilkan distribusi dan persentase dari tiap variabel. Selanjutnya dilakukan analisis bivariat menggunakan paired t-test untuk mengetahui perbedaan kadar hemoglobin sebelum dan sesudah perlakuan dan independent sample t-test untuk mengetahui perbedaan kadar hemoglobin ibu hamil anemia 
yang mendapat suplementasi tablet Fe dan tablet $\mathrm{Fe}$ dengan madu dengan tingkat kepercayaan $95 \%(\alpha 0,05)$.

Penelitian ini sudah memperoleh rekomendasi persetujuan etik pada Komisi Etik Penelitian Kesehatan Politeknik Kesehatan Kementerian Kesehatan Makassar dengan Nomor: 009/KEPK-UK/VII/2016.

HASIL

Tabel 1. Distribusi Frekuensi Karakteristik Ibu Hamil Anemia

\begin{tabular}{lrr}
\hline \multicolumn{1}{c}{ Variabel } & n & \% \\
\hline Umur (tahun) & 3 & \\
$<20$ & 25 & 83 \\
$20-35$ & 2 & 7 \\
$>35$ & & \\
Umur kehamilan & 3 & 10 \\
Trimester I & 20 & 67 \\
Trimester II & 7 & 23 \\
Trimester III & & \\
Gravida & 8 & 27 \\
$\quad$ Primigravida & 22 & 73 \\
$\quad$ Multigravida & 19 & 63 \\
Status Anemia Sebelum Perlakuan & \\
$\quad$ Anemia Ringan & 11 & 37 \\
$\quad$ Anemia Sedang & \\
Status Anemia Setelah Perlakuan & \\
$\quad$ Tidak Anemia & 9 & 30 \\
$\quad$ Anemia Ringan & 19 & 63 \\
$\quad$ Anemia Sedang & 2 & 7 \\
\hline
\end{tabular}

Tabel 1 menunjukkan responden yang paling banyak adalah ibu berusia 20-35 tahun (83\%). Usia kehamilan ibu yang paling banyak adalah ibu dengan usia kehamilan trimester II (67\%). Gravida yang paling banyak adalah ibu multigravida (73\%). Sebelum diberikan perlakuan terdapat $63 \%$ ibu dengan anemia ringan dan 37\% ibu dengan anemia sedang. Setelah diberikan perlakuan terdapat $30 \%$ ibu hamil dengan tidak anemia, 63\% ibu dengan anemia ringan dan $7 \%$ ibu dengan anemia sedang.

Tabel 1. Rerata \pm SD Kadar Hemoglobin Ibu Hamil Sebelum dan Sesudah Pemberian Tablet Fe dan Madu

\begin{tabular}{lccc}
\hline Kadar Hb & \multicolumn{3}{c}{ Kelompok } \\
& $(\mathbf{n = 1 5 )}$ & $\begin{array}{c}\text { Fe+Madu } \\
(\mathbf{n = 1 5})\end{array}$ & $\begin{array}{c}\boldsymbol{p} \\
\text { value }^{2}\end{array}$ \\
\hline $\begin{array}{l}\text { Kadar Hb } \\
\text { sebelum } \\
\text { perlakuan }\end{array}$ & $9,65 \pm 0,69$ & $8,69 \pm 1,04$ & \\
$\begin{array}{l}\text { Kadar Hb } \\
\text { setelah } \\
\text { perlakuan }\end{array}$ & $9,96 \pm 1,37$ & $9,75 \pm 1,11$ & 0,653 \\
\hline palue & 0,371 & 0,0005 & \\
\hline
\end{tabular}

Tabel 2 menunjukkan rata-rata dan standar deviasi kadar hemoglobin ibu hamil sebelum dan sesudah perlakuan. Uji paired t-test menunjukkan tidak ada perbedaan yang bermakna kadar haemoglobin sebelum dan sesudah pemberian tablet Fe (kontrol) dengan nilai $p$-value $=0,371$. Ada perbedaan yang bermakna kadar hemoglobin ibu hamil sebelum dan sesudah pemberian tablet Fe dan madu dengan nilai $p$-value $=0,0005$. Uji independent sample t-test menunjukkan tidak ada perbedaan yang bermakna kadar hemoglobin setelah pemberian tablet $\mathrm{Fe}$ dengan pemberian tablet Fe dan madu ( $p$-value=0,653), walaupun tidak ada perbedaan tapi bila dibandingkan persentasi peningkatan kadar $\mathrm{Hb}$ ibu hamil anemia menunjukkan peningkatan $\mathrm{Hb}$ yang diberi tablet $\mathrm{Fe}$ dan madu lebih tinggi dibandingkan yang hanya diberi tablet Fe. Kadar $\mathrm{Hb}$ ibu hamil anemia yang diberi tablet $\mathrm{Fe}$ hanya mengalami peningkatan sebesar $0,31 \mathrm{gr} / \mathrm{dl}$ $(3,212 \%)$, sedangkan yang diberi tablet $\mathrm{Fe}$ dan madu mengalami peningkatan sebesar 1,06gr/dl $(12,198 \%)$

\section{PEMBAHASAN}

\section{Karakteristik Responden}

Hasil penelitian menunjukkan responden yang paling banyak adalah ibu berusia 20-35 tahun, walaupun masih ditemukan ibu hamil yang berusia $<20$ tahun dan $>35$ tahun. Usia ibu merupakan faktor risiko terhadap kejadian anemia. Hal ini sejalan dengan hasil penelitian yang dilakukan oleh Jasmi (2016) yang menyatakan adanya hubungan faktor usia dengan kejadian anemia pada ibu hamil, dimana peluang ibu hamil yang berisiko tinggi terhadap umur 15 kali lebih cenderung mengalami anemia dibandingkan ibu hamil dengan umur berisiko rendah. Begitu juga dengan penelitian Udu, Yulia, dan Asryani (2014) menunjukkan bahwa responden dengan usia $<20$ tahun dan $>35$ tahun memiliki risiko 7,21 kali untuk mengalami anemia dibandingkan dengan responden dengan usia 20-35 tahun.

Anemia pada ibu hamil secara fisiologis terjadi akibat adanya pengenceran darah, akibat peningkatan volume darah selama masa kehamilan yang lazim disebut hidraemia atau hipervolemia. Pertambahan sel darah yang kurang dibandingkan dengan bertambahnya plasma menyebabkan terjadi pengenceran darah. Perbandingan tersebut adalah plasma (30\%), sel darah (18\%), dan hemoglobin (19\%). Bertambahnya darah dalam kehamilan sudah 
dimulai sejak kehamilan 10 minggu dan mencapai puncaknya pada usia 32 dan 36 minggu, yang berarti semakin tinggi umur kehamilan ibu maka semakin rendah kadar hemoglobinnya (Wiknjosastro, 2012). Usia kehamilan ibu yang paling banyak pada penelitian ini ibu dengan usia kehamilan trimester II. Hal ini sejalan dengan penelitian yang dilakukan Sjahriani dan Faridah (2019) yang menunjukkan kejadian anemia defisiensi besi pada wanita hamil meningkat sesuai dengan tuanya usia kehamilan. Apabila tidak diimbangi dengan pola makan yang seimbang dan konsumsi Fe secara teratur akan meningkatkan resiko anemia.

Gravida atau yang sering disebut paritas adalah jumlah anak yang telah dilahirkan oleh seorang ibu baik lahir hidup maupun lahir mati. Seorang ibu yang sering melahirkan mempunyai risiko mengalami anemia pada kehamilan berikutnya apabila tidak memperhatikan kebutuhan nutrisi. Hal ini disebabkan karena selama hamil zat-zat gizi akan terbagi untuk ibu dan janin yang dikandungnya. Berdasarkan hasil penelitian yang paling banyak adalah ibu multigravida. Hal ini sejalan dengan hasil penelitian yang dilakukan oleh Yuliastuti, Tutiana, dan Syahlani (2014) yang menyatakan terdapat hubungan antara paritas dengan kejadian anemia pada ibu hamil. Ibu hamil dengan paritas 1 atau lebih dari 3 memiliki risiko lebih tinggi mengalami anemia dan kematian maternal. Penelitian yang dilakukan oleh Astriana (2017) juga menyatakan ada hubungan paritas dengan kejadian ibu hamil anemia.

\section{Pemberian Kombinasi Madu dan Tablet Fe terhadap Peningkatan Hemoglobin Ibu Hamil Anemia}

Hasil penelitian ini menunjukkan tidak ada peningkatan yang bermakna pemberian tablet $\mathrm{Fe}$ terhadap kadar hemoglobin ibu hamil anemia. Faktor yang mempengaruhi kadar hemoglobin ibu hamil tidak meningkat dengan pemberian tablet $\mathrm{Fe}$ yaitu ketidakpatuhan terhadap suplementasi yang diberikan sejak awal kehamilan. Pemantauan konsumsi tablet $\mathrm{Fe}$ selama penelitian (14 hari) tidak memberikan peningkatan yang bermakna terhadap peningkatan kadar hemoglobin ibu hamil. Ketidakpatuhan terjadi karena efek samping yang ditimbulkan setelah mengkonsumsi tablet $\mathrm{Fe}$. Efek samping tersebut meliputi efek samping pada saluran pencernaan (mual, rasa nyeri dan muntah), pusing serta efek pada saluran pencernaan bawah seperti diare dan konstipasi (sulit buang air besar). Kurangnya pengetahuan ibu juga mempengaruhi kepatuhan mengkonsumsi tablet $\mathrm{Fe}$, seperti warna feses yang berubah membuat ibu cemas dan takut untuk melanjutkan mengkonsumsi tablet $\mathrm{Fe}$ tersebut. Hal ini sejalan dengan penelitian yang dilakukan oleh Laksana, Widiastuti, Krisnansari, dan Soenarto (2012) yang menyatakan bahwa efektivitas terapi anemia dengan tablet besi hanya $41,9 \%$, sehingga disimpulkan efektivitas pemberian tablet besi terhadap anemia pada ibu hamil rendah.

Usaha lain yang dapat dilakukan adalah pemberian treatment sebagai supplement support yang bertujuan untuk mempercepat peningkatan kadar hemoglobin pada ibu hamil anemia. Salah satu suplementasi yang dapat diberikan adalah madu. Madu adalah cairan kental yang dihasilkan oleh lebah madu dari berbagai sumber nektar. Kandungan zat besi pada madu dapat mensintesis pembentukan heme yang dapat memacu peningkatan kadar hemoglobin, sehingga dapat disimpulkan bahwa mengkonsumsi madu dapat mencegah anemia defisiensi besi pada ibu hamil (Wulandari, 2015).

Hasil penelitian ini menunjukkan kadar hemoglobin ibu hamil meningkat $1,06 \mathrm{gr} / \mathrm{dl}$ setelah mengkonsumsi madu. Peningkatan ini bisa diakibatkan karena madu banyak diminati ibu hamil, sehingga dapat mengurangi efek samping yang dirasakan ibu saat mengkonsumsi tablet Fe. Madu juga mengandung vitamin C yang dapat mempermudah penyerapan zat besi sehingga dapat mempercepat peningkatan kadar haemoglobin pada ibu hamil. Zat besi dalam madu dapat digunakan sebagai prekursor pembentukan hemoglobin pada sumsum tulang (Wulandari, 2015).

Penelitian yang dilakukan Islamiyah, Hafizah, dan Wulandari (2017) menunjukkan peningkatan kadar hemoglobin setelah pemberian madu pada remaja putri Kelas X yang mengalami anemia di SMKN 01 Mempawah Hilir. Demikian juga penelitian yang dilakukan oleh Ristyaning dan Susane (2016) yang menyatakan mengkonsumsi madu pada remaja yang menderita anemia dapat membantu meningkatkan pembentukan sel darah merah dan mencegah anemia. Berdasarkan penelitian di atas kandungan madu yang kaya dengan zat-zat pembentuk sel darah merah seperti zat besi $(\mathrm{Fe})$ juga mampu meningkatkan hemoglobin pada ibu hamil anemia. Madu dapat dijadikan sebagai alternatif pilihan untuk mengatasi anemia pada ibu hamil. 


\section{SIMPULAN}

Kadar hemoglobin ibu hamil anemia yang diberi tablet $\mathrm{Fe}$ dan madu lebih signifikan peningkatannya dibandingkan dengan yang hanya diberi tablet Fe. Diharapkan hasil penelitian ini dapat memberi alternatif untuk peningkatan hemoglobin ibu hamil anemia,

\section{DAFTAR PUSTAKA}

Astriana, W. (2017). Kejadian Anemia pada Ibu Hamil Ditinjau dar Paritas dan Usia. Aisyah: Jurnal Ilmu Kesehatan, 2(2), 123-130.

Citrakesumasari. (2012). Anemia Gizi, Masalah dan Pencegahannya. Kalika (1st ed.). Yogyakarta: Kalika.

Dinas Kesehatan Kab. Mamuju. (2015). Profil Dinas Kesehatan Kabupaten Mamuju Tahun 2015. Mamuju: Dinkes Kabupaten Mamuju.

Fisher, A. L. (2020). The Physiology and Pathology of Iron in Pregnancy. University of California. https://escholarship.org/uc/item/0th2s0ss

Islamiyah, N. (2017). Pengaruh Madu Terhadap Kadar Hemoglobin Remaja Putri Kelas X Yang Mengalami Anemia di SMKN 01 Mempawah Hilir. Jurnal ProNers, 3(1).

Jasmi. (2016). Hubungan antara Paritas dan Umur dengan Kejadian Anemia pada Ibu Hamil di Puskesmas Melur Kecamatan Sukajadi Kota Pekanbaru. Jurnal Ibu Dan Anak, 1(2), 43-50.

Kementerian Kesehatan RI. (2013). Riset Kesehatan Dasar. Jakarta: Kemenkes RI.

Kementerian Kesehatan RI. (2016). Profil Kesehatan Indonesia Tahun 2015. Jakarta: Kemenkes RI.

Khan, S. U., Anjum, S. I., Rahman, K., Ansari, M. J., Khan, W. U., Kamal, S., Khan, H. U. (2018). Honey: Single Food Stuff Comprises Many Drugs. Saudi Journal of Biological Sciences, 25(2), 320-325. http://doi.org/10.1016/j.sjbs.2017.08.004

Laksana, A. S. D., Widiastuti, R., Krisnansari, D., \& Soenarto. (2012). Efektivitas Pemberian Tablet Besi terhadap Anemia pada Ibu Hamil di Puskesmas 1 Kembaran sehingga masalah anemia pada ibu hamil dapat diatasi. Hasil penelitian ini juga dapat dijadikan sebagai rujukan dalam melaksanakan pengabdian kepada masyarakat, karena berdasarkan observasi peneliti masih ada ibu hamil khususnya di Kaupaten Mamuju yang belum memeriksakan kehamilannya ke fasilitas kesehatan disebabkan jarak yang cukup jauh.

Kabupaten Banyumas. Prosiding Seminar Nasional Kesehatan Jurusan Kesehatan Masyarakat FKIK UNSOED (pp. 1-8). Purwokerto: Jurusan Kesehatan Masyarakat FKIK Unsoed.

Ristyaning, P., \& Susane, I. M. A. (2016). Madu Sebagai Peningkat Kadar Hemoglobin pada Remaja Putri yang Mengalami Anemia Defisiensi Besi. Majority, 5(1), 49-53.

Sjahriani, T., \& Faridah, V. (2019). FaktorFaktor Yang Berhubungan Dengan Kejadian Anemia Pada Ibu Hamil. Jurnal Kebidanan, 5(2), 106-115.

Syuhar, M. N., Windarti, I., \& Kurniawaty, E. (2014). Perbandingan Tingkat Kesembuhan Luka Bakar Derajat II Antara Pemberian Madu Dengan Tumbukan Daun Binahong Pada Tikus Putih (Rattus Norvegicus) Galur Sprague Dawley. Jurnal Majority, 3(5).

Udu, W. S. A., Yulia, A., \& Asryani, S. W. (2014). Faktor-Faktor Risiko Usia, Asupan Tablet Fe dan Status Gizi yang Berhubungan dengan Kejadian Anemia pada Ibu Hamil. Medula, 2(1), 131-133.

WHO. (2015). The Global Prevalence of Anaemia in 2011. WHO. Geneva: World Health Organization.

https://apps.who.int/iris/handle/10665/177094

Wiknjosastro. (2012). Ilmu Kebidanan. Jakarta: EGC.

Wulandari, P. (2015). Honey to Prevent Iron Deficiency Anemia in Pregnancy. $J$ Majority, 4(3), 90-95.

Yuliastuti, E., Tutiana, A., \& Syahlani, A. (2014). Hubungan Pendidikan dan Paritas Ibu dengan Kejadian Anemia pada Ibu Hamil. Dinamika Kesehatan, 5(2), 109-117. 